\title{
Kaebekirjade kiituseks ehk kommentaariks ühele arhivaalile ${ }^{1}$
}

Tiina Saluvere

Et kommenteerida Methise seekordset arhiivileidu, tuleks kõigepealt meenutada veidi ühiskondlikku tausta ja sündmusi eesti teatriloos, mille keskel publitseeritav kiri on kirjutatud. 1964. aasta kevadel puhkes Irdi-aegse Vanemuise suurim kriis, mille käivitas pealtnäha tühine põhjus: üks ajaleheartikkel. Kriis kestis ligikaudu kaks kuud, selle aja jooksul peeti arutu hulk koosolekuid, toimus poleemika ajakirjanduses, Vanemuise olukorra uurimiseks moodustasid Eesti NSV Kultuuriministeerium ja EKP Keskkomitee komisjoni, Kaarel Ird esitas lahkumisavalduse, kuid soostus hiljem siiski teatrijuhina jätkama. Olgu siinkohal lühidalt meenutatud sündmuste kronoloogia.

Kriisi näiliseks vallapäästjaks oli Leenu Siimiskeri artikkel „Juubelijärgseid küsimisi-kostmisi, milles tehakse juttu William Shakespeare'ist, „Coriolanusest”, „Vanemuise” teatrist ja tema külastajatest” 10. mai ajalehes Edasi. Arvustades Irdi lavastatud „Coriolanust”, millega teater tähistas Shakespeare'i juubelit, toob Siimisker välja mitmeid probleeme Vanemuise üldistes arengutes: repertuaaripoliitikas, kaadrivalikus jm. Retsensent heidab teatrile (eeskätt siis teatrijuhile) ette liiga kergekaaluliste näidendite domineerimist mängukavas. Artikkel sisaldab küll omajagu kriitilisi nooli, kuid distantsilt lugedes ei saa seda hinnata eriliselt kurjaks või pahatahtlikuks, ammugi mitte selliseks pommiks, mis võis tingida järgneva sündmuste arengu.

EKLA-s Irdi fondis on nelja koosoleku protokollid (EKLA, f 307, m 195: 3), mis kõik kajastavad antud probleemiga tegelemist, päevakorras ikka samad punktid: olukord teatris ja Siimiskeri artikli arutamine. Nii peetakse 27. mail 1964 draamarühma koosolek, 29. mail kunstinõukogu koosolek, 6. juunil töötajate-veteranide tootmisnõupidamine ja 24. juunil Vanemuise töötajate üldkoosolek, millest võtavad osa ka kultuuriministeeriumi, EKP Tartu linnakomitee, ajalehtede Izvestija, Sovetskaja Estonia ja Edasi esindajad. Lisaks neile toimub sama probleemideringi käsitlevaid koosolekuid veel ilmselt ka väljaspool teatrimaja (kultuuriministeeriumis, parteikomitees jm).

"Coriolanusest" on koosolekutel vähe juttu, arutatakse teisi Siimiskeri artiklis esile toodud probleeme: repertuaaripoliitikat, näitlejate rakendatust, teatri võimaliku Moskvagastrolliga seotud asjaolusid jne. Palju räägitakse näitlejate ja lavastajate/juhtkonna suhetest ja Irdi konfliktsest iseloomust. Ird tundub olevat Siimiskeri artikli peale sügavalt solvunud. Ird hindas oma (ja muudegi Vanemuise) lavastuste taset enamasti üsna adekvaatselt, tehes selget vahet kunstil ja konjuktuursetel kaalutlustel tehtud töödel, olgu viimaste põhjused siis

1 Publikatsioon on valminud sihtfinantseeritava teadusteema "Kultuuriloo allikad ja kirjanduse kontekstuaalsus" (SF0030065s08) raames. 
majanduslikud (publikumenukas, kuid kunstiliselt väheväärtuslik repertuaar) või poliitilised (kohustuslikud tähtpäevalavastused). Pragmaatilistel kaalutlustel tehtud lavastuste puhul tavatses ta sageli kasutada väljendit, et need peaksid olema vähemalt sellisel tasemel, et „Ioll ei saa aru ja tark ei tule ütlema”. Vsevolod Višnevski „Esimese ratsaväe”2 kavvavõtmine oli selgelt teatripoliitiline käik, mille abil Ird lootis Vanemuise viia Kremli Teatrisse. Kui Siimisker oma artiklis sellest nüüd halvustavalt kõneles, osutus ta Irdi silmis selleks targaks, kes siiski tuli ütlema, kuigi ta mängureeglite järgi ei oleks pidanud seda tegema.

Samal ajal jätkub poleemika ajakirjanduses. Johannes Feldbach avaldab 12. juuni Edasis artikli „"Coriolanuse” lavastusest ja selle puudustest ning puuduste põhjustajatest”, kus esitab vastuväiteid Siimiskeri artiklile. Kui Siimisker pidas nõrgaks lavastaja tööd, siis Feldbach osutab puudustele näitlejate töös ning peab lavastaja kontseptsiooni õigeks ja huvitavaks. Arvustuse avalõik viitab teatri ümber käimas olevale konfliktile, mainides, et "Coriolanuse" lavastuse puhul avaldatud sõnavõtud on kasvanud mõttevahetuseks „Vanemuise” üle, tema lavastajate kunstipoliitika joone, teatri kollektiivi meisterlikkuse, teatri perspektiivide ja muu säärase üle" (Feldbach 1964). Siiski piirdub arvustaja oma artiklis "Coriolanuse” üle arutlemisega, lubades kõnelda „muudest probleemidest, mis on vaidlusalused, teinekord" (samas). Sama kuupäeva (12.06.) Sirbis ja Vasaras ilmub kümne tuntud kirjaniku ${ }^{3}$ allkirja kandev „Kiri „Vanemuise” teatri kollektiivile”, kus osutatakse Irdi suurtele teenetele Vanemuise juhina ja tuntakse muret, mis saab Vanemuisest Irdi võimaliku lahkumise korral.

21. juunil võtab taas sõna vastasleer: sama päeva Edasis ilmuvad Kalju Haani artikkel „Kuhu on jäänud näitleja loominguline individuaalsus?” ja Ants Järve, August Luuri, Abel Nagelmaa ja Ülo Tontsu allkirju kandev kirjutis „Teatriprobleem ootab vastutustundelist lahendamist". Haan polemiseerib Feldbachiga, väites, et teatris ei tehta piisavalt lavapedagoogilist tööd, ei anta näitlejatele võimalusi kasvuks ja arenguks. Nelja mehe pöördumine on aga teatavaks vastulauseks kirjanike avalikule kirjale ja vaidlustab mõningad seal esitatud väited. Siin juhitakse avalikult tähelepanu probleemidele, mis on suuresti seotud Irdi konfliktse iseloomu ja käitumisstiiliga ning osutatakse, et kriisisituatsioon ei ole tekkinud ootama-

\section{Lavastas Epp Kaidu.}

3 Avalikule kirjale on alla kirjutanud Villem Gross, Jaan Kross, Erni Krusten, Uno Laht, Kersti Merilaas, Ralf Parve, Lilli Promet, Paul Rummo, Johannes Semper, Debora Vaarandi. Huvitav on märkida, et Vaapo Vaher oletab oma Liivese-monograafias sellest konfliktist ja kirjanike avalikust kirjast rääkides, et Ardi Liives oleks olnud ilmselt raskustes, kui keegi temalt oleks sellele kirjale allkirja küsinud, sest ühelt poolt oli tal küll Irdiga olnud hea koostöö algupärandite lavale toomisel, kuid teisalt oli ta ka Irdi kohta palju negatiivset kuulnud. "Kuid õnneks Liiveselt keegi allkirja ei palunud. Kirjale olid käe alla pannud väärikad figuurid," resümeerib Vaher irooniliselt (Vaher 2007: 169). See näiliselt tühine seik lisab nii mõndagi Irdi suhtlusvõrgustike iseloomustamiseks: ka need, kes tundusid olevat temaga ühes paadis, nautisid tema positsiooniga seotud toetust, ei pruukinud teda kriitilisel hetkel ise sugugi toetada. 
tult, vaid „rea aastate jooksul on kuhjunud teatrisse endasse ja teatri ümber palju rahulolematust ning rohkesti tõsiseid, edukat tööd takistavaid konflikte, millede lahendamine on muutunud pakiliseks, teatri arengu seisukohalt edasilükkamist mittesallivaks ülesandeks" (Järv jt 1964).

Vastukaja nelja mehe kirjutisele ilmub 3. juuli Sirbis ja Vasara rubriigis „Meie materjale jälgides”. Pealkirja „Veel „Vanemuisest”” kandev anonüümne, ilmselt toimetuse seisukohti väljendav lühilugu on ühtlasi kokkuvõte Vanemuise-teemalisest poleemikast ja kriisisituatsioonile Iõpplahenduse toonud teatri üldkoosolekust. Lõpetuseks avaldatakse arvamust, et „viisil, kuidas 21. juuni „Edasis” trükitud sõnavõtu „Teatriprobleem ootab vastutustundelist lahendamist" autorid asetavad kahtluse alla üldiselt lugupeetud kirjanike õiguse ja pädevuse teatri asjades kaasa rääkida, pole midagi ühist asjaliku ja soliidse poleemikaga küsimuses, mille soodsast lahendamisest me kõik oleme huvitatud” (Veel „Vanemuisest” 1964).

Järgmine lehelugu antud teemal ilmub 19. juulil. Sel korral võtab Edasi veergudel sõna EKP Tartu Linnakomitee sekretär Armilde Jürimäe, kelle artikkel kannab pealkirja „Veel kord „Vanemuisest””. Et selleks ajaks on koosolekud peetud ja Irdi jätkamine teatrijuhina otsustatud, on see justkui kokkuvõtteks möödunud sündmustest. Üsnagi mahukas (pea tervet ajalehe lehekülge täitev) artikkel on kirjutatud rahulikus toonis, kuid tajutav on poolehoid Vanemuise juhtkonna seisukohtadele. Kriitika Siimiskeri ja tema mõttekaaslaste pihta on vürtsitatud ideoloogiliste hinnangutega, nagu osutamine nõukogude kunsti parteilisusele jms. Nii näiteks avaldab Jürimäe kahetsust, et Siimisker suhtub irooniaga Vanemuise soovi minna esinema Kremli Teatrisse ja Višnevski „Esimese ratsaväe” repertuaari võtmisse sel eesmärgil, kuigi tuleks eeldada, et „esinemine Kremli Teatris on igale meie maa kunstikollektiivile suureks auks ja küpsuseksamiks" (Jürimäe 1964).

Olgu lisatud, et poleemika jätkus sügisese teatrikuu raames, selle avas Ird oma artikliga „Teater ja vaataja” 20. novembri Noorte Hääles. Olgugi et esmapilgul tundub tegu olevat juba uue poleemikaga, võib eelnevat tausta teades leida n.ö „Coriolanuse”-poleemikaga siiski üsnagi palju seoseid, eriti muidugi Irdi ja Siimiskeri artiklites.

Selline on sündmuste väline kulg, kui püüda seda rekonstrueerida eeskätt ajakirjandusallikatele toetudes. Samas on ütlematagi selge, et ajaleheartikkel, olgu see kuitahes terav, ei saa olla piisav põhjus nii ulatusliku kriisi vallandumiseks. Kui piirduda ka üksnes ajaleheartiklite ja koosolekute protokollide lugemisega, on siiski tajutav, et kuskil pinna all on veel miski, millest eriti ei räägita, kuid mis mõjutab oluliselt sündmuste kulgu. Selgust aitavad tuua arhiiviallikad.

Koosolekute ja ajakirjandusliku poleemikaga paralleelselt käib tihe kirjavahetus. Kirju kirjutavad ja saadavad mõlema leeri esindajad, adressaatideks nii Tartu, Tallinna kui Moskva partei- ja võimuesindajad. Kõige mastaapsemaks aktsiooniks on 19 vanemuislase allkirjaga kirja saatmine EKP Keskkomiteele (koopiad ENSV Kultuuriministeeriumile ja EKP Tartu linnakomiteele). Kiri on publitseeritud Jaak Villeri monograafias „Kandiline Kaarel Ird” (Viller 
2009: 452-457). Tähelepanuväärne on, et kuigi kõik, kes sündmust veel isiklikult mäletavad või on sellest kirjutanud, ei kahtle, et kirja (peamiseks) autoriks oli Jaan Saul, siis Sauli allkirja kirjal pole. Tõsi, Saul on selleks ajaks Vanemuise koosseisust lahkunud ja Moskvasse õppima suundunud, ometi ei takista see teda osalemast Vanemuise üldkoosolekul, kus suure vastasseisu üle aru peetakse.

Jaan Saul (1936-1966) oli TRK lavakunstikateedri I lennu lõpetaja, kes pärast teatrikooli asus näitlejana tööle Vanemuise teatrisse, kus leidis kohe rakendust kandvates rollides. Peagi leidis aga noor näitleja, et koolis õpitu ja tegelik teatritöö on teataval määral vastuolus. Aktiivse inimesena asus ta tegutsema. Sauli toetajateks ja kaasvõitlejateks olid kirjandus- ja teatriuurijad Leenu Siimisker (1924) ja Linda Krigul (1906-1996) ning hiljuti Ugalast Vanemuisesse tulnud noor näitleja, Sauli kursusekaaslane Ines Parker (Aru, 1939). Võitluse lipukirjaks oli Stanislavski meetodi tõlgendamine, eesmärgiks Irdi kukutamine.

1964. aasta kriisist Vanemuises on tegelikult kirjutatud üsna palju (Siimisker 1972, Tonts 2006, Viller 2009 jmt), nii võib esmapilgul tunduda, et kõik on ajaloo jaoks selgeks räägitud, kõik allikad ammendatud. Ometi see päris nii ei ole. Kõik nende sündmustega seotud arhiiviallikaid ei ole kahjuks kättesaadavad. Nii ei ole ka Jaak Villeril õnnestunud leida Sauli kirja Moskva võimukandjatele (vt Viller 2009: 431), kuid selle olemasolu kohta leidub viiteid mitmetes teistes allikates. Arvestades Venemaa arhiivide keerulist olukorda, ei pruugi need allikad eesti uurijaile lähiajal kättesaadavad olla. Kaudsed allikad (nii suulised kui kirjalikud mälestused) kõnelevad koguni Sauli kirjast Nikita Hruštšovile, kuid siin võib olla tegemist ka teatava hüperboliseerimisega. Tõepärasem on oletus, et kiri oli adresseeritud tolleaegsele NLKP KK kultuuriosakonna juhatajale Polikarpovile. Sellele väitele võib tuge leida ka Sauli kirjavahetusest. Kui aga oletada, et Saul pöördus oma kirjaga tõepoolest Hruštšovi poole, nagu on arvanud Reet Neimar (vt Viller 2009: 431), siis on üsna tõenäoline, et see kiri ei olegi säilinud, vaid on makuleeritud kui tundmatu inimese pöördumine tühise probleemiga.

Lisaks leidus aga veel teisigi kirju, mille adressaatideks olid kohalikud võimukandjad, kuid mille mõte ja eesmärk samad. Oma salapäraga pingestasid nad niigi pingelist õhkkonda veelgi. Paine, millest seni oli avalikkuse ees vaikitud, julges sõnastada Herta Elviste, kes 27. mail draamarühma koosolekul ütles: „Ird kogu aeg räägib mingisugustest anonüümsetest kirjadest. Kus need on ja mis sisulised nad on? Tahaks teada, sest on selline tunne, et Ird võib mõelda, nagu oleksin mina neid kirjutanud. Niisugune tunne võib olla igaühel meist." (EKLA, f 307, m 195: 3, I 14/42)

Kes ja kellele neid anonüümseid kirju selle kriisi käigus või enne selle puhkemist on saatnud, on üsna keeruline, kui mitte võimatu tagantjärele tuvastada. Ometi leidub ka EKLA-s Irdi fondis üks pakk kirju, mille sisuks on võitlus „Irdi-Kaidu diktatuuri” vastu Vanemuises, eesmärgiks Irdi teatrijuhi kohalt kõrvaldamine. Säilik kannab arhiivis pealkirja „Jaan Sauli kirjavahetust", kuid sisaldab ka mõningaid teiste autorite tekste. Osalt on need kaebekirjad 
võimuesindajatele, osalt vandenõulaste omavaheline korrespondents. Adressaadid on omavahelistes kirjades sageli peidetud eufemistlike nimetuste taha, nt „malevlane”, „rahvavaenlane". Kirjad pärinevad aastaist 1964-1966. Tegemist on masinakirjakoopiatega, mis arhiivi jõudes olid kiirköitjaga ühendatud.

Sellised arhiiviallikad tekitavad hulgaliselt küsimusi. Kas ja kuivõrd võib neid pidada autentseiks? Kas pole viimati tegemist fabritseeringuga? Kui nii, siis kes ja mis eesmärgil võis selle valmistada? Kui need on aga ehtsate kirjade koopiad, siis peaksid kuskil leiduma ka originaalid. Kuidas sattus vastasleeri kirjavahetus Irdi kätte? Kas keegi mängis topeltmängu? IImselt seetõttu ongi neile kirjadele arhiiviallikaina seni väga ettevaatlikult lähenetud. Olgugi et 1964. aasta sündmustest Vanemuises on kirjutatud küllalt palju, on sealjuures üsna tähelepanuväärne, et üks selliseid keskseid konflikti olemust kajastavaid allikaid on kas üldse kõrvale jäetud (Siimisker 1972, Tonts 2006) või kasutatud väga napilt ja üksnes riivamisi (Viller 2009).

Mõistagi ei ole taoliste allikate usaldusväärsus tõepoolest 100\%-line, kuid ka tõekindla päritoluga allikate puhul ei saa me nende sisu ju kunagi päris 100\%-liselt uskuda, eriti nõukogude perioodi uurimisel mitmesuguseid egodokumente kasutades, mille kirjutamisel võis rolli mängida nii tsensuur kui enesetsensuur ja suur hulk teisigi mõjureid. Orlando Figes on osutanud allikatega seotud probleemidele oma raamatus "Sosistajad. Eraelu Stalini Venemaal", väites, et just allikate nappuse ja tsensuurist-enesetsensuurist tulenevate tõlgendusraskuste tõttu on nõukogude aja, eriti stalinismi-perioodi uurijad üha enam võtnud kasutusele suulise ajaloo menetlusviise (Figes 2010: 34-35). Ühtlasi tähendab see toetumist vähem traditsioonilistele allikatele. Nii Figesi kui ka paljude mikroajaloolaste tööd tõestavad, et alternatiivsetele ja marginaalsetele allikatele toetudes on võimalik luua vägagi adekvaatseid ja üldistavaid käsitlusi. Tundub, et nõukogude kultuuriloo, eriti kultuuripoliitika uurimisel võiks seni marginaalseks peetud allikate poole pöördumine olla produktiivne. ${ }^{4}$

Jaak Viller kirjutab oma Irdi-monograafias, et „arhiividest ei õnnestunud leida kirjalikke märke Sauli kirjadest NL-i ametiasutustesse, nagu ka näha seda „5 sentimeetri paksust dokumendipakki, kuid järgnenud sündmusi arvestades ei saa seda kirja „kõige kõrgemale” ka päris võimatuks pidada" (Viller 2009: 431). Tolle $5 \mathrm{~cm}$ paksuse kausta kohta meenutas Lilian Vellerannale 1999. aastal intervjuu andnud Reet Neimar, kes 1964. aastal oli üliõpilane, järgmist: „Nähes, et Ird on üliõpilaste seas populaarseks muutunud, et konverentside

4 Omamoodi paralleelnähtusena võiks mainida arhiiviallikate kasutamist kunstiteoste loomisel. Siingi tundub suund olevat n.ö subjektiivsemat laadi allikate poole. Näiteks Ivar Põllu lavastus "Ird, K." (2010) Tartu Uues Teatris, mida on esile tõstetud põhjaliku arhiivitöö eest, tugineb suures osas Irdi fondis leiduvatele Irdile saadetud anonüümkirjadele. Andrus Kivirähk võttis oma Pansost rääkiva näidendi "Voldemar" (Eesti Draamateater, 2007) aluseks aga Panso päevikud. Mõlemad teatritekstid ja lavastused on suutnud luua üsna tõepärase pildi ja mõjusa kunstilise üldistuse nii konkreetsetest isikutest kui ka ajastust. Järelikult leidub taolistes subjektiivsetes arhiiviallikates midagi sellist, mis võimaldab jõuda objektiivsete üldistusteni. 
kaudu on toimunud Irdi ja üliõpilaste lähenemine, laskis Siimisker ja kompanii /Villeri vahemärkus: Siimiskeri väitel küll ainult Linda Krigul/ käiku $5 \mathrm{~cm}$ paksuse köite kõikvõimalike koopiatega Irdi ja Sauli võitluse dokumentidest. Selle mõttega, et vaadake ometi, missugune see Ird on. Meie lugesime ja arutasime - see kaust käis kohvikus käest kätte - et mõeldud on see üheks, aga meie loeme siit välja hoopis teist." (Viller 2009: 430-431) Siinkirjutaja julgeb oletada, et EKLA-s leiduv säilik Sauli ja tema mõttekaaslaste kirjavahetusega ongi tegelikult seesama „5 cm paksune köide” või vähemasti osa sellest. Olgugi et siinsel kirjapakil on paksust vaid cm jagu, ei tundu väga võimatu uskuda, et see mälestustes 35 aasta jooksul, mis intervjuud kõnealustest sündmustest lahutasid, 5-kordsed mõõtmed omandas, seda enam, et selle sisu lugejat vapustas. See annaks ka lihtsa ja loogilise vastuse küsimusele, mil kombel sai see kirjapakk Irdi kätte jõuda.

Järgnevalt publitseeritav kiri on üks tollest pakist. Samahästi oleks see võinud olla ka mõni teine. Näib, et konkreetsest kirjast olulisemgi on tuua tänase lugejani see retoorika, mis selliseid pöördumisi iseloomustab, samuti tutvustada taolistes intriigides kasutusel olnud vahendeid, kuna selles on paljugi ajastule iseloomulikku. Tähtis pole mitte niivõrd see, kes on konkreetse kirja autor, kuivõrd see, et niisuguste vahenditega loodeti (ja ehk mõnikord ka õnnestus?) oma eesmärke saavutada.

Kas on siis põhjust väita, et Sauli-Siimiskeri-Kriguli tegutsemine oli alatum või ebaeetilisem kui Irdi oma - või vastupidi: kirjad „kõrgemale poole” olid levinud strateegiliseks võtteks ju ka Irdi arsenalis? Mõnes mõttes on tõesti tegemist omamoodi kultuuripoliitilise võttega, mis nõukogude ühiskonnas oli vististi üsna laialt levinud. Ometi võib neid kirju omavahel võrreldes leida kaks olulist erinevust. Irdi kirjade sõnum on reeglina plussmärgiline - ta võitles millegi poolt, eeskätt Vanemuise jaoks mitmesuguseid hüvesid taotledes. Seejuures ei püüdnud ta konkurente halvustada, nende tegevust kahtluse alla seada. Vastasleeri paatos on aga pigem destruktiivne, miinusmärgiline. Kui Irdi kirjades on dominandiks see positiivne programm, mille teostumist takistavad vaid mõned abstraktsed jõud, nagu bürokraatide rumalus vms, siis Sauli leeri kirjade puhul on olukord vastupidine: negatiivsena ja kõrvaldamist vajavana on kujutatud konkreetsed isikud, positiivseks pooleks vaid abstraktse-võitu „rahva usaldus”, Stanislavski süsteem, eetika jms. Teiseks oluliseks erinevuseks on see, et Ird ei valinud kunagi kirja adressaati üksnes ametikohast lähtuvalt, eelduseks, et kirja abil soovitud tulemust saavutada, oli ikkagi eelnev isiklik suhe selle inimesega, millest sõltus suuresti kirja stiil.

Näib ehk veidi paradoksaalne, kuid mitte päris ebaloogiline, kui väita, et Saulist oleks võinud saada Irdile väga hea mantlipärija, kes oleks jätkanud Irdi ühiskondlik-poliitilise teatri suunda ja osanud asju ajada võimumeeste kaudu. Kui meenutada näiteks Irdi ja Evald Hermaküla kirjavahetust, siis sealne tonaalsus ja probleemidering erineb nn Sauli-diskursusest kardinaalselt. Teemaks on eeskätt kunstiprobleemid, ka eraelulised seigad, kuid „poliitikat me ilmselt keegi teha ei oska ja see on väga tõsine puudujääk," kirjutab Hermaküla Irdile 
3. detsembril 1969 (EKLA, f 307, m 12: 34), pidades siin meie all silmas lisaks endale Jaan Toomingat, Mati Unti ja Kuno Otsust. Sauli aga huvitas justnimelt poliitika ja juhtimineorganiseerimine. Lisaks sellele oli ta väga hea näitleja, kel oli eeldusi saada ka heaks lavastajaks. Aga Saul kiirustas, sest tal ei olnud aega oodata ja paraku saigi Sauli aeg otsa ${ }^{5}$ enne, kui Ird tahtis tunnistada, et tema aeg otsas on. ${ }^{6}$ Kui võrrelda Sauli Hermakülaga, on raske uskuda, et nende vanusevaheks oli vaid viis aastat - kirjade põhjal tundub neid lahutavat vähemalt põlvkond. Ehk olid siis just need mõned aastad olulised teistsuguse teatrist mõtlemise tekkeks? Või taandub küsimus siiski isiksuseomadustele?

Publitseeritav kiri on dateerimata, kuid kirja sisu põhjal võib väita, et see on kirjutatud 1964. aasta sügisel. Kuigi kriis oli jaanipäevase suure koosolekuga justkui Irdi kasuks lahenenud, ei loobunud vastasleer siiski veel võitluse jätkamisest. See tuleb ilmsiks ka teisi samas säilikus leiduvaid kirju lugedes: võitlus Irdi kukutamise nimel kestab tegelikult veel 1966. aasta algulgi, viimane kiri kõnealuses arhivaalis, mille autoriks on tõenäoliselt Jaan Saul, kannab daatumit 8. märts 1966 ja seal tõmmatakse üsna jõuliselt paralleele Irdi ja Hitleri vahel ning kurdetakse, et „EKP kongress ei toonud ka mitte mingeid muutusi, kuigi eelõhtul oli kuuldusi liikvel. Nii et ikka tuleb ajada asja vana sõbra LL-iga7. Ja jälle mitu aastat. Ning kes siis lõpuks kord paneb paigale Epu ja Kaareli, teenitud paigale?" (EKLA, f 307, m 272: 8, 1 6/43) Seega hõõgub Irdi-vastase leeri võitlusvaim kuni Noorsooteatri asutamiseni. Kas sellest võiks järeldada, et küsimus oli siiski eeskätt teatrijuhi ametikohas Voldemar Panso jaoks? See ei tundu siiski eriti usutav, pigem oletaksin Sauli võimuambitsiooni ${ }^{8}$, mille realiseerimiseks uus teater uusi perspektiive ja võimalusi avas. Paraku lahkus Jaan Saul napilt viis kuud pärast Noorsooteatri avamist elavate hulgast.

Mil määral oli konfliktiga seotud Voldemar Panso? Jaak Viller on oletanud, et just Panso võis olla see, kelle jaoks taheti Irdi koht vabastada, kuna ta oli sel hetkel ainus tõsiselt võetav kandidaat sellele kohale (Viller 2009: 418-420). Panso huvist Vanemuise juhtimise vastu ei leidu mingeid märke, pigem suhtub ta sündmustesse distantseeritult. Maris Balbati poolt publitseeritud Panso kirjast Saulile võib lugeda: „Vanemuise sündmustega pole ma päris kursis. Kui Rootsi kuningriigist tulin, kuulsin, et rahu pandi kehtima. [---] Siimiskerilt sain kirja, ta pisut informeeris. Küllap olete kõigi nende sündmustega palju targemaks saanud." (Panso Saulile 29.07.1964 - Balbat 2000) Panso roll sündmustes oli pigem kaudne. Et Saul

\footnotetext{
5 Saul põdes rasket südamehaigust ja teadis arstide prognoosi oma lühikeseks jääva eluea kohta.

6 Ird oli konflikti ajal 54-aastane, nii ei soovinud ta arusaadavalt ohje veel käest anda.

7 Leonid Lentsman.

8 Sauli huvile võimu vastu viitab näiteks seegi, et ta oli astunud väga noore mehena NLKP ridadesse ja oli Tartu Linna TSN rahvasaadik.
} 
ja Parker olid Panso õpilased, seostus nende tegevus paratamatult mingil määral ka õpetaja isikuga, tekitades Irdis tõruva hoiaku Panso-kooli lõpetanute suhtes. 1964. aasta kriis on ühtlasi murdepunktiks Irdi ja Panso suhetes, just siit saab alguse hiljem lausa müütilise tähenduse omandanud suur vastasseis.

Pansot ja Irdi on vastandatud ja võrreldud väga palju (vt nt Tormis 2006, Viller 2009, Krõmova 2010 jmt), kõigest sellest ülevaate andmine ei mahu siinse käsitluse raamidesse. Olgu siis vaid osutatud mõnele arhiivispetsiifilisele seigale, markeerimaks põgusalt mõnd seni vähem tähelepanu leidnud aspekti. On paratamatu, et ajalugu kirjutades saab toetuda eeskätt neile arhivaalidele, mis on uurijale kättesaadavad, kuid kes vähegi arhiiviallikatega töötanud, teab ka, et allikaid ei leidu kaugeltki kõige kohta, mis uurijat huvitaks. Allikaile toetudes on meil tihtipeale võimalik rekonstrueerida vaid osa tervikpildist, Jacques Reveli (2005: 151) määratlust kasutades katkelised tasandid. Mõnikord võib aga allikate puudumine olla sama kõnekas kui allikad ise. Nii tundub see olevat, kui püüda leida kõnealuste sündmuste kajastusi Panso arhiivis, mille olemasolule teised allikad viitavad. Kuigi Panso kirjast Saulile võib lugeda, et Siimisker on talle sündmustest kirjutanud (Balbat 2002), ei leia me arhiivist ei Siimiskeri ega Sauli selleteemalisi kirju. Nii tundubki antud teema puhul olevat tegemist omamoodi unustuste reaga, mis algab Leenu Siimiskeri monograafiaga Jaan Saulist, kus kõnealustest sündmustest pea vaikides mööda mindud, mis Sauli kui võtmefiguuri rolli arvestades ei ole ootuspärane, ja lõpeb Panso selle perioodi päevikute salapärase kadumisega arhiivist.

Kuid kas ei tundu selle taustal siis kummaline, et kirjapakk, mille hulgast pärineb ka siin publitseeritav kiri, on siiski säilinud, veelgi enam, seda on koguni paljundatud ja teadlikult levitatud? Mõistagi jõuame siit taas ka kahtlusteni autentsuse ja allika usaldusväärsuse küsimuses. Üritamatagi siinkohal neile probleemidele ammendavaid vastuseid leida, näib siiski, et oluline on teadvustada ka sedalaadi allikate olemasolu ja ärgitada lugejat mõtlema nõukogude perioodi uurimisega seotud allikakriitiliste probleemide üle.

\section{K i r j a n d u s}

Figes, Orlando 2010. Sosistajad. Eraelu Stalini Venemaal. Tallinn: Varrak.

Krõmova, Natalja 2010. Kas te armastate teatrit? Artikleid ja arvamusi. Koostanud Lea Tormis. Tallinn: Eesti Teatriliit.

Revel, Jacques 2005. Jacques Reveli intervjuu Marek Tammele. - Marek Tamm. Kuidas kirjutatakse ajalugu? Intervjuuraamat. Tallinn: Varrak, 2007, Ik 145-160.

Siimisker, Leenu 1972. Jaan Saul. Monograafia. Tallinn: Eesti Raamat. 
Tonts, Ülo 2006. Kolmkümmend aastat teatriehitamist. „Vanemuise” sõnateatrist 1955-1986. Tartu: Vanemuine.

Tormis, Lea 2006. Teatrimälu. Koostanud Piret Kruuspere ja Hando Runnel. Tartu: IImamaa.

Vaher, Vaapo 2007. Imelaps, kellest ei saanud geeniust. Esseistlik monograafia Ardi Liivesest. Tallinn: Eesti Keele Sihtasutus.

Viller, Jaak 2009. Kandiline Kaarel Ird. Dokumente ja kommentaare. Tallinn: Eesti Teatriliit.

\section{K äs i ki r ja li s ed a I likad}

Hermaküla, Evald. 8 kirja Kaarel Irdile. 31. dets. 1966 [p.o 1967] + d-ta, osaliselt käsitsi, osaliselt masinakiri. - EKLA, f 307, m 12: 34.

Saul, Jaan. Kirjavahetust. 1964-1966, masinakiri, koopiad. - EKLA, f 307, m 272: 8.

"Vanemuise" koosolekute protokolle. 1948-1964. - EKLA, f 307, m 195: 3.

\section{Trükiallikad}

Balbat, Maris 2000. Panso kirjadest Lauterile, Saulile ja Reegile. - Maaleht, 30. XI. http://www.hot.ee/aaslavtepandi/voldemar.htm - vaadatud 18. IV 2011.

Feldbach, Johannes 1964. „Coriolanuse” lavastusest ja selle puudustest ning puuduste põhjustajatest. - Edasi, 12. VI.

Haan, Kalju 1964. Kuhu on jäänud näitleja loominguline individuaalsus? - Edasi, 21. VI.

Ird, Kaarel 1964. Teater ja vaataja. - Noorte Hääl, 20. XI.

Järv, Ants jt 1964. = Ants Järv, August Luur, Abel Nagelmaa, Ülo Tonts. Teatriprobleem ootab vastutustundelist lahendamist. - Edasi, 21. VI.

Jürimäe, Armilde 1964. Veel kord „Vanemuisest”. - Edasi, 19. VII.

Kiri „Vanemuise” teatri kollektiivile 1964. - Sirp ja Vasar, 12. VI.

Siimisker, Leenu 1964a. Juubelijärgseid küsimisi-kostmisi, milles tehakse juttu William Shakespeare'ist, „Coriolanusest”, „Vanemuise” teatrist ja tema külastajatest. - Edasi, 10. V.

Siimisker, Leenu 1964b. Mõtisklegem koos Kaarel Irdiga teatriküsimuste üle. - Noorte Hääl, 9. XII. Veel „Vanemuisest” 1964. - Sirp ja Vasar, 3. VII.

Tiina Saluvere on Eesti Kirjandusmuuseumi kultuuriloolise arhiivi toimetaja ja Tartu Ülikooli teatriteaduse doktorant. Peamised uurimissuunad: nõukogude perioodi teatrilugu ja kultuuripoliitika. Kontakt: tiina@kirmus.ee. 
Vale on orjade ja isandate religioon...

Tõde - vaba inimese jumal!

GORKI

\section{V.a. Tartu Linnakomitee sekretär sm. VI. Meister.}

Kui kommunist ning inimene, kes meie näitekunsti arengut on teadlikult jälginud sajandi kahekümnendaist aastaist peale (1926-da aastani Tallinnas, siis Tartus, 1946-1949 a. kirjandusala juhataja „Vanemuises" ${ }^{9}$ ), kes omab tagasihoidlikult öeldes sel alal ka mõningaid teadmisi, tunnen, et olen kohustatud avaldama Teile oma seisukohad seoses meie linna ainsa kutselise teatriga. Tunnistan kahetsusega, et viimasel ajal ma pole avalikult sõna võtnud meie teatri jooksva töö osas. Sel kevadel oli mul plaanis kirjutada üks ülevaade „Vanemuise” tööst ja tegevusest, selgitada ta arenguliin niihästi kaugema mineviku kui ka meid ümbritseva Nõukogude Liidu teatrielu positsioonilt. Niisuguste teatri ülevaadete puudusele, teatavasti, juhtis tähelepanu möödunud aasta novembris teostatud esimene teatrikuu ${ }^{10}$.

Tahtsin hakata kirjutama ülevaadet. Kuid ei saanud. Tundsin, et sellele on pannud keelu peale see ebaterve õhkkond, mis tekkis sm. Siimiskeri tunnustust vääriva artikli ${ }^{11}$, hiljem ka teiste viie autori artiklite ${ }^{12}$ ümber. Ütlen siinkohal kohe välja, et ma täiel määral jagan kõigi artiklite vaatekohti. On tubli, et tõde pääses vähemalt kordki me nii rangelt kriitikat vältivas ajakirjanduses võidule. Need kirjutised on sündinud siirast ja aastaid kestnud südamevalust ning on ülekohtune neist selliste vägisõnaliste tembeldamistega jagu saada, nagu seda suurel koosolekul13 on teinud meie parteiline ja valitsusline juhtkond ning muidugi eelkõige Ird-Kalvo ${ }^{14}$. Tõde ei saa lööksõnadega matta. On tõsiselt kahju, et ühe inimese positsiooni

9 Kuigi kirjal puudub allkiri, on selle tutvustuse põhjal võimalik öelda, et kirja autoriks on Linda Krigul.

10 Esimest korda tähistati teatrikuud ETÜ eestvõttel 1963. aasta novembris, eesmärgiks tihendada sidemeid teatri ja publiku vahel, pöörata teatrile rohkem tähelepanu jne. Hiljem kujunes teatrikuuks märts, mil tähistatakse ka rahvusvahelist teatripäeva.

11 Siimiskeri artikkel "Juubelijärgseid küsimisi-kostmisi, milles tehakse juttu William Shakespeare'ist, "Coriolanusest", "Vanemuise" teatrist ja tema külastajatest" 10.05.1964 ajalehes Edasi.

12 Siin on mõeldud A. Järve, A. Luuri, A. Nagelmaa ja Ü. Tontsu allkirju kandvat kirjutist "Teatriprobleem ootab vastutustundelist lahendamist" ja K. Haani "Kuhu on jäänud näitleja loominguline individuaalsus", mõlemad 21.06.1964 Edasis.

13 Vanemuise töötajate üldkoosolek 24.06.1964, millest võttis osa ka teatri tööd kontrollinud komisjon, kultuuriminister Laus, EKP Tartu linnakomitee sekretärid, ajalehtede Izvestija, Sovetskaja Estonia ja Edasi esindajad.

14 S.t Kaarel Ird ja Vanemuise toonane korraldajadirektor Arved Kalvo. 
kindlustamiseks (rahvas kõneleb tollest koosolekust kui „,isikukultuse üheksandast lainest”) mängitakse käest usaldus, millega partei ja ministeeriumi poole pöördus grupp vanemuislasi ${ }^{15}$ ja mis oli ka omane valdavale osale töötajaist üldse. Seltsimehed ootasid tõde ja õigust ning said... jah, mida nad küll said... Kollektiivi ei peetud sellegi vääriliseks, et oleks nende poolt avaldatud soovile lugeda ette kokkuvõte komisjoni ${ }^{16}$ tööst - reageeritud millegi muuga kui vaid „piinliku vaikusega”. (Poleks vist liigne olnud kõnelda siin tollest salapärasest koosolekust, mis peeti päev varem Linnakomitees. ${ }^{17}$ )

Igatahes ei ole ma näinud midagi masendavamat kui need segipaisatud ja pinna otsekui jalge alt kaotanud inimesed, kes ei osanud mõelda, kuidas võis üks koosolek nii toorelt minna mööda nende kõige parematest soovidest, kuulata neid ära, kuid jääda jonnakalt oma juurde. Ja seda ajal, kus Moskvas oli olnud nii mitu murrangulist parteikongressi ${ }^{18}$, mis kõik suunasid leninlike ühiselu normide ja vabaduste taastamisele. See aga...

Tean, et see rabas mind ennastki, kes ma olen n.ö. omal nahal saanud tajuda, mis tähendab isikukultus ${ }^{19}$. Niisugune koosolek oleks võinud olla veel võimalik tosinkond aastaid tagasi, kuid mitte nüüd. Mitte kuidagi nüüd! Et see aga sai võimalikuks, see fakt paneb juurdlema nähte pärispõhjuste üle ja otsima vastust. Vastuse viimasele võib küllap saada rahvalt endalt, kes juba Stalini päevil nägi tõde ja ütles ka tõde välja, kuigi meist väga, väga paljud ei tahtnud seda uskuda. Ja rahval on praegugi omad arvamused mõneski asjas. On vaid kahju, et Tartu Linnakomitee kui siinne kohapealne lähim parteiline instants ei ole siiani pidanud küllaldast sidet rahvaga.

Ülalt kamandamisega me ei jõua kaugele. Me võime tekitada ainult umbusaldust ja vaenugi seal, kus meid ootavad lahtised südamed. Kas see on siis mõistlik ja kooskõlas partei programmiga? Kas ei peaks astuma lähemale ka „Vanemuise” põhiliselt toredale kollektiivile. Rahvast ammutas oma jõu ja tarkuse Lenin - miks ei võiks meie teha sama,

15 Vihje Jaan Sauli poolt algatatud kaebekirjale, millele kirjutas alla 19 vanemuislast.

16 Kaebekirjas esitatud probleemide uurimiseks ja lahendamiseks loodi keskkomitee ja kultuuriministeeriumi poolt komisjon, kes kontrollis Vanemuise tööd, vestles töötajatega jne.

17 Praegusele lugejale tundub see väide ilmselt pisut kummaline, kuna info EKP linnakomitee koosolekust on vaatamata selle "salapärale" kirja autorile siiski teada.

18 Kuna NLKP kongressid toimusid siiski mitme aasta (reeglina 5) tagant, on siin vihjatud ilmselt pikemale perioodile, mis algas XX kongressiga 1956. aastal, kus Nikita Hruštšov pidas oma Stalini isikukultust paljastava ajaloolise kõne. XXI kongress toimus 1959 ja XXII kongress 1961.

19 Seda väidet ei saa väga tõsiselt võtta, pigem on siin tegemist ajastule omase suuna järgimisega, millele vastavalt on antud hetkel soovitav olla kannatanud isikukultuse all ja nüüd seda hukka mõista. Linda Krigul töötas aastail 1945-1948 Vanemuise kirjandusala juhatajana, 1948-1951 Kirjandusmuuseumi arhiivraamatukogu juhatajana ja aastail 1951-1959 õppis Moskvas GITIS-es teatriajalugu. 
pealegi, kus see on meie otsene kohustus. Kabinetist ja ühekülgse informatsiooniga ei saa juhtida ühtki elulõiku, kaugeltki mitte säärast keerukat asutust nagu „Vanemuine”.

Smd Lentsman ${ }^{20}$ ja Kalvo kõnelesid midagi taolist, nagu oleks Siimiskeri artikkel ilmunud ebaõigel ajal ${ }^{21}$. Kuid milline siis olnuks too õige aeg? Muidugi, artikkel võinuks ilmuda ehk vähemalt paar aastat varem. Siis ehk meil poleks vaja olnud registreerida praaki pea kogu möödunud hooaja töös, lavastajate tööluusi hooaja lõpul22, mille tõttu 2 etendust jäid välja toomata ning nihkub tavalisest üle kuu kaugemale selle hooaja esimene esietendus ${ }^{23}$. Kuid et seda artiklit oleks võinud tundigi edasi lükata - sellega ei saa nõus olla. Kas siis Moskva jaoks ${ }^{24}$ on vaja võõbata „Vanemuine” paremaks kui ta on? Kas poleks õigem olla parem, selle asemel, et vaid näida paremana ${ }^{25}$.

(Isiklikult tegin 1962. aasta juunis katse „Sirp ja Vasara” juures üldsuse signaliseerimiseks, kuid artikkel tembeldati pärast kuuaegset seismist toimetuses ja ilmset ringlemist võibolla isegi Irdideni välja - sihilikuks, kirjutatud Irdi isiklikult vaenlaselt. Eks ole see sama demagoogiline võte, mida kasutas ka Kalvo ja Ird, iseloomustades Siimiskeri artiklit ja mille osaliseks nüüd ja edaspidi saab igaüks, kes söandab kritiseerida teatri tegevust.)

Veel tollest suurest koosolekust: Miks ei võtnud siin sõna ükski teatri parteiline ega ühiskondlik organisatsioon, miks jäi passiivseks ka Tartu Linna parteiorganisatsioon? Kas ei leidu Partei põhikirjas siiski sätteid, mida kommunist ei tohi ignoreerida kunagi. Olgu ta siis millisel kohal tahes.

Masendav, nagu suur koosolek, oli ka sm. Jürimäe artikkel EDASI veergudel26. See oli kirjutatud nii Irdi häälega, et sellisena on seda võtnudki teatrirahvas ise ja ma kaldun sellest

20 Leonid Lentsman oli kõnealusel ajal EKP KK ideoloogiasekretär, ühtlasi oli ta Vanemuise tööd kontrollinud komisjoni esimeheks.

21 Kuna just Siimiskeri artikkel sai kriisi vallandajaks, siis tuleks silmas pidada kogu konfliktsituatsiooni ajastatust. Irdi strateegiasse kuulus teatavasti Vanemuise viimine üleliidulisele areenile, et võita seeläbi teatrile laiemat tunnustust ja parandada majanduslikku olukorda. Just intriigi puhkemise ajal oli korraldamisel üleliidulise ajalehe Izvestija teatrikülastajate konverents Vanemuises, mis kujunenud olukorra tõttu ära jäi.

22 Vihje sellele, et koosolekute pidamise perioodil kannatas tavapärane töö teatris, proovid jäid ära.

23 Hooaja 1964/65 esimeseks esietenduseks Vanemuises oli Brechti "Kolmekrossiooper" Epp Kaidu lavastuses, esietendus toimus 25. oktoobril. Kirja autori väide on teatud määral siiski demagoogiline, sest olgugi et eelmise hooaja esimene esietendus oli toimunud septembri lõpul, oli üle-eelmisel hooajal esimese esietendusega publiku ette jõutud alles novembri algul, nii on väide viivituse kohta mõnevõrra liialdatud.

24 Mõeldud Vanemuise kavandatud külalisetendusi Moskvas Kremli Teatris, samuti ehk ka Izvestija konverentsi.

25 Selle väitega võib teatud määral nõustuda, sest näib, et Ird kippus (eriti Moskvasse pürgimise algaastail) Vanemuise taset mõnikord tõesti üle hindama.

26 EKP Tartu linnakomitee sekretäri A. Jürimäe artikkel "Veel kord "Vanemuise" teatrist" 19.07.1964 Edasis. 
välja lugema koguni sõnasõnalisi laene Irdilt. Sest kuidas küll sm. Jürimäe, kes oli ju ette teadlik sm. Siimiskeri artikli seisukohtadest, kes neid seisukohti oli heaks kiitnud, nüüd siis äkki asus teistele positsioonidele ${ }^{27}$. Oli see kirjutis peale surutud, ette dikteeritud? Kas oli selle avaldamisega arvestatud, millise löögi anti rahva tõe ja õiguse tunnetele kui siingi, nagu koosolekulgi loomingulistelt probleemidelt nihutati küsimused majanduslike ja organisatsiooniliste küsimuste valdkonda ning töömeetodist, käitumisstiilist ${ }^{28}$ libiseti kollektiivi piitsutamisele mõningate distsipliinirikkumiste puhumisega keskseteks küsimusteks. Paraku olid need distsipliinirikkumisedki serveeritud nähtuna Irdi silmadega, nagu kas või lugu Terniga ${ }^{29}$, mis oli vaid Irdi seletusvariant.

Hämmeldama paneb ka lugedes seda kirjutist, kuidas meil ei teata - või ei taheta teada - kõige algelisemat tõde, - et nõukogude teatri aluseks on eetika ${ }^{30}$, seega puhas loominguline õhkkond. Stanislavski tahtis koguni kirjutada eetika kohta eriraamatu, pidades eetika küsimust äärmiselt tähtsaks. Pruugib lugeda Stanislavski „Eetikat” ${ }^{31}$ praeguselgi kujul ja N. Gortšakovi raamatust „K. S. Stanislavski näitejuhtimistunnid” 32 (mõlemad olemas ka eesti keeles) paarikümmend lehekülge, et teha oma eitav otsus sellele „süsteemile”, millega Irdid lavastavad ja kiuste millele (mitte aga mille tõttu) tänu näitlejate omaalgatusele on suudetud eesti teatriajalukku kirjutada siiski mõned kaunid ja tunnustatavad leheküljed. Loomingulisest õhkkonnast aga sm. Jürimäe kõneleb kui pisiprobleemist, mis lõhnavat intrigeerimise järgi ja millest tulevat olla üle. Ei, loominguline õhkkond, mis peab baseeruma loovate inimeste omavahelistele ausatele ja väärikatele suhetele - eetikale, on see, millega teater hingab ja elab. Puudub see - käib teater paratamatult alla ja tekivad konfliktid, mida pea seaduspärase

27 Selle lause on Ird (?) EKLA-s leiduval eksemplaril alla kriipsutanud. Väide on tähelepanuväärne seetõttu, et siit ilmneb selgelt, et ka Siimiskeri artikli näol oli tegemist EKP Tartu Linnakomitee ja selle häälekandja Edasi tellimustööga, mida Siimisker Jaak Villerile antud intervjuus on ka kinnitanud (vt Viller 2009: 433-434, 443-444).

28 Irdi töömeetodist ja käitumisstiilist ei ole ajaleheartiklites tõesti kuigi palju juttu, kuid koosolekutel teatris olid need teemad üsna avameelselt ja valusalt jutuks, nagu võib lugeda koosolekute protokollidest (EKLA, f 307, m 195: 3).

29 Arhiiviallikatest nähtub, et näitlejanna Valentine Terni puhul oli probleemiks sagedane proovidesse hilinemine.

30 Stanislavskile ja eetikale rõhumine ning Irdi ja tema töömeetodi vastandamine neile on keskseks teemaks ka Sauli kirjades ning Siimiskeri monograafias "Jaan Saul". Teatavasti oli Stanislavski süsteemi dogmaatiline ja vulgariseeritud rakendus nõukogude teatris ainuvalitsevaks olnud kogu stalinismi-perioodi, kõnealusel perioodil hakati aga Eestis juba huvi tundma Brechti ideede vastu ja vaid mõni aasta hiljem tõid noored teatriuuendajad siinsesse kultuuripilti Grotowski, Artaud' jt märksa radikaalsemad teatriideed.

31 Konstantin Stanislavski. Eetika. Tallinn: Eesti NSV Teatriühing, 1952.

32 Nikolai Gortšakov. K. S. Stanislavski näitejuhtimistunnid: vestlused ja proovide üleskirjutused. Tallinn: Eesti Riiklik Kirjastus, 1963. 
perioodisusega peavad lahendama igasugused komisjonid ja artiklid. Sest kus pole inimarmastust, kus näitlejat ei loeta inimeseks ja kus lavastaja pole kommunist tegudes vaid ainult sõnades, kus puudub kollektiivne looming, kus ei rakendata näitleja mõtlemisvõimet aastate, aastakümnete kaupa - seal hakkab midagi mõranema teatri alustugedes. Seda enam kui kollektiiv on täienenud eriharidusega ja väga haritud ning tublide jõududega, kes ei taha ega saa harjuda töötamast nn. „paarisrääkimise” ${ }^{33}$ suretaval meetodil, jättes kasutamata tolle rikkaliku arsenali, mille on meile pärandanud Stanislavski.

Ma olen kindel, et see kinnimätsimise ja demokraatia rikkumise juhtum niihästi suurel koosolekul kui ka sm. Jürimäe kirjutises, ei ole sündinud võitluseta. Miks muidu peeti Linnakomitees too salapärane pikk koosolek eelmisel päeval, millest rahvale ei öeldud sõnagi? Tähendab tõeleeril tuli veel ennast võitluses alla anda. Selleasemel, et rõõmustada, et rahvas ise mõtleb, et ise algatab suure probleemi ja teeb ometi kord suu lahti ning ajab ennast sirgu - nüüd kõrgemalt poolt sajab talle roikaid. Sest olukorda teati mitte ainult nende paljude anonüümsete kirjade põhjal, mida olevat kogunenud ministeeriumisse, vaid ka vestlustest kollektiivi liikmetega ja väljastpoolt. Mäletan, kuidas mulle seletas üks ministeeriumi töötaja (oli vist sm. Ojamaa), et oleks vaja, et algatus tuleks avalikult kollektiivi enda poolt, siis saaks ka ministeerium midagi ette võtta. Nüüd see algatus tuli, kuid vahepeal oli ministeerium otsustanud nähtavasti lahtisilmi mitte midagi näha. Enamik sõnavõtjaist koosolekul rääkis ju ühte ${ }^{34}$, kuid Keskkomitee ning Kultuuriministeerium oma esindajate näol seisid müürina väljas oma eest...

Ja veel üks küsimus: miks sm. Jürimäe ei rääkinud artiklis ENSV rahvakunstnikust Ellen Liigerist ${ }^{35}$, keda on palgalehel viidud kategooria madalamale, kuigi ta ise ei ole andnud selleks oma nõusolekut, keda on tahetud viia koguni invaliidsusepensionile, et vaid andekast ja suurte teenetega näitlejast lahti saada. Kes on küll andnud Irdidele-Kalvole õiguse röövida rahvalt ta talente?! Meil ei ole sugugi neid nii palju, et võiksime nendega pillata. See väide, nagu oleks näitlejate mittekasutamine teistegi teatrite „haigus”, on ju pärit samast allikast, kust jutt, et „Vanemuisel” pole midagi mängida, kuna üleliiduliselt on dramaturgiaga halvad lood. Jaa, see väide ei vabanda antud nähtu praegu kuidagi. Meenub kodanlik Eesti, kus Leopold Hansen suunati pensionile loomingulises õitseeas - 48-aastaselt! -, kus Liina Reiman, Amalie Konsa tõugati õitseeas eesti kutseliselt lavalt lihtsalt maha. Leidus selliseid „asjatundjaid”! Milleks peame meie nõukogude korras sääraseid väärnähteid kordama?!

33 Nii nimetati Irdi kommet proovides näitlejate teksti kaasa rääkida.

34 Koosolekul avaldati siiski vägagi erinevaid seisukohti.

35 Ellen Liigeri puhul tasub ehk meenutada, et ta oli Voldemar Pansole küllaltki lähedane isik, Panso noorusarmastus, nagu selgub Panso päevikutest. Seega võis Ird (põhjusega või mitte) kahtlustada tema puhul n.ö Panso huvide esindamist, kui oletada, et kogu konflikti üks eesmärke võis olla Irdi asendamine Pansoga. 
Meenutagem põlise tartlase Velda Otsuse sunnitud lahkumist Tartust ta kolmekümneaastase lavajuubeli eelõhtul! Oo jaa, talle lubati vist kindlustada 1000 rublane personaalpensiongi. Näitleja olevat ju ennast tühjaks mänginud. Ning ometi säras ja hiilgas Otsus Gittelina „Kahekesi kiigel” 36 Tartu külaskäigul! Milline pillamine! Näitlejate nii ohtrat lahkumist Tartust ei saa siiski välja vabandada mingi „ümberformeerumisega" või ütelusega, et „Vanemuine” on Tallinna kasvulavaks. Lasta ära minna tõesti andekatel inimestel nagu Kilgas, Tern, rääkimata NSVL rahvakunstnikust A. Lauterist ja Viisimaast! Ja lõpuks on siis nüüd lahkunud Tartust Tallinna Nõukogude „Vanemuise” üks loojaid, ENSV teeneline kunstitegelane, „Vanemuise” peakunstnik V. Peil! Kas ei jätku tema „korralekutsumise” lugudest ühe süsteemi tõelise olemuse avamiseks. Läinud on Ines Parker, Engman ${ }^{37}$. Valdo Truvel ${ }^{38}$ oli tollel koosolekul tõepoolest viimane sõnavõtt „Vanemuise” ruumides, (kuigi distsipliinirikkumise tõttu tuli tal lahkuda). ${ }^{39}$

Nii. Mida rohkemat? Võibolla ma murran praegu Teie juures lahtisest uksest sisse. Küllap Teie jagate kõike eelöeldud suuremal või vähemal määral. Arvan, et komisjoni materjal oli küllaltki värvirikas ja iseloomulik, nagu oli seda suur koosolekki.

Tahaks loota, et olete juba otsustanud anda vabaks diskussioon, kui mitte midagi rohkemat ${ }^{40}$. Sest jutt on jäänud ju pooleli. Õieti pole ta saanudki päriselt alustada, sest kõik artiklid ilmusid mingis ärevas keelamis-käskimise õhkkonnas. Diskussiooni vägivaldne lõpetamine, suure koosoleku reportaaži ärakeelamine, see kõik on ju, õrnalt öeldes, taunitav juhtum. Pärast XXII kongressi...

36 William Gibsoni "Kahekesi kiigel" lavastas 1963. aastal Draamateatris Leo Kalmet, osades Velda Otsus ja Ants Eskola.

37 Roland Engman (1935), kes oli õppinud Draamateatri õppestuudios, töötas näitlejana aastail 1956-1963 Pärnu teatris, 1963-1964 Vanemuises, 1964-1966 taas Pärnu teatris ja 1966-1971 Draamateatris. Hiljem tegutses toiduainetetööstuse alal.

38 Valdo Truve (1925-1991) oli õppinud TRK-s laulmist, töötanud lauljana Estonia kooris (1945-1947) ja näitlejana Noorsooteatris (1947-1948), aastail 1955-1964 oli Vanemuise solist. Vanemuisest lahkumise järel töötas aasta Rakvere teatris, hiljem Estonia kooris.

39 Näitlejate lahkumine Vanemuisest oli kahtlemata tõsine probleem, mis sageli tulenes tõesti konfliktidest Irdi ja Kaiduga. Ometi oli minekuks teisigi põhjuseid, eeskätt avaramad ja mitmekesisemad võimalused pealinnas, mis on oluliselt mõjutanud näitlejate valikuid ja otsuseid ka muudel aegadel.

40 Pöörduda kohaliku parteijuhi poole, et ta diskussiooni vabaks annaks, tundub juba iseenesest olevat demokraatiat välistav, seega on vabast diskussioonist nii või teisiti raske rääkida. Kuid diskussioon tõepoolest jätkus, küll mitte päris sellise rõhuasetusega, nagu siinse kirja autor silmas pidas, kuid teatriloolises mõttes kahtlemata märksa huvitavamalt ja suuremaid üldistusi pakkuvalt. Sama aasta novembris sai Noorte Hääles alguse poleemika, mis jätkus veel ka järgmisel aastal ja mille teemaks olid teatri ja publiku suhted, keskseks probleemiks see, miks vaataja eelistab sageli alaväärtuslikumat teatritükki korralikule klassikalavastusele. Krigul poleemikas ei osalenud. 
Olen üks neid, kes tahaks võtta sõna. Las kirjutavad ka näitlejad, publiku esindajad, kriitikud. Las vaidlevad. See vaielus ei saa kunagi olla nõukogudevastane ei kuidagi ohtlik ei meie reputatsioonile, ei ühelegi välis- või sisepoliitikale. Peaasi - tõde kooruks välja. Pealesunnitud vaikuses on aga kerge ujuda vaenlastel, kes inimeste vigu, kes esindavad parteid, samastavad partei enda oletatava vigasusega. Rohkem usaldust, inimlikkust ja peaasi - tulgu partei rahva sekka! Vaadaku ise. Siis ei vii vildak informatsioon kedagi valeteedele ning aegavõtvad ning närvekulutavad ülearusused (küll oleks selle ajakuluga võinud palju ära teha!) jääksid ära.

Andestage kui olen olnud ehk liiga äge ja järsk. Kuid need asjad valutavad, sest need on meie sotsialistliku kultuuri tõsised ja sügavad probleemid, millest ei saa niisama mööda minna.

Kommunistliku tervitusega 